NASA/TM-2007-215035

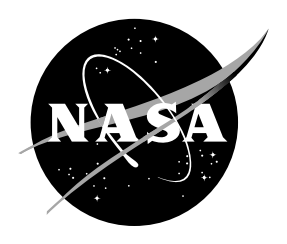

\title{
Feasibility Study of Vapor-Mist Phase Reaction Lubrication Using A Thioether Liquid
}

Wilfredo Morales

Glenn Research Center, Cleveland, Ohio

Robert F. Handschuh and Timothy L. Krantz

U.S. Army Research Laboratory, Glenn Research Center, Cleveland, Ohio 


\section{NASA STI Program . . . in Profile}

Since its founding, NASA has been dedicated to the advancement of aeronautics and space science. The NASA Scientific and Technical Information (STI) program plays a key part in helping NASA maintain this important role.

The NASA STI Program operates under the auspices of the Agency Chief Information Officer. It collects, organizes, provides for archiving, and disseminates NASA's STI. The NASA STI program provides access to the NASA Aeronautics and Space Database and its public interface, the NASA Technical Reports Server, thus providing one of the largest collections of aeronautical and space science STI in the world. Results are published in both non-NASA channels and by NASA in the NASA STI Report Series, which includes the following report types:

- TECHNICAL PUBLICATION. Reports of completed research or a major significant phase of research that present the results of NASA programs and include extensive data or theoretical analysis. Includes compilations of significant scientific and technical data and information deemed to be of continuing reference value. NASA counterpart of peer-reviewed formal professional papers but has less stringent limitations on manuscript length and extent of graphic presentations.

- TECHNICAL MEMORANDUM. Scientific and technical findings that are preliminary or of specialized interest, e.g., quick release reports, working papers, and bibliographies that contain minimal annotation. Does not contain extensive analysis.

- CONTRACTOR REPORT. Scientific and technical findings by NASA-sponsored contractors and grantees.
- CONFERENCE PUBLICATION. Collected papers from scientific and technical conferences, symposia, seminars, or other meetings sponsored or cosponsored by NASA.

- SPECIAL PUBLICATION. Scientific, technical, or historical information from NASA programs, projects, and missions, often concerned with subjects having substantial public interest.

- TECHNICAL TRANSLATION. Englishlanguage translations of foreign scientific and technical material pertinent to NASA's mission.

Specialized services also include creating custom thesauri, building customized databases, organizing and publishing research results.

For more information about the NASA STI program, see the following:

- Access the NASA STI program home page at http://www.sti.nasa.gov

- E-mail your question via the Internet to help@sti.nasa.gov

- Fax your question to the NASA STI Help Desk at 301-621-0134

- Telephone the NASA STI Help Desk at 301-621-0390

- Write to: NASA Center for AeroSpace Information (CASI) 7115 Standard Drive Hanover, MD 21076-1320 
NASA/TM-2007-215035

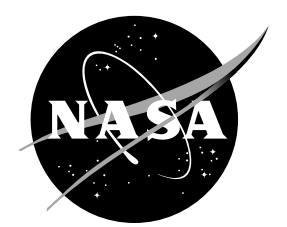

\section{Feasibility Study of Vapor-Mist Phase Reaction Lubrication Using A Thioether Liquid}

Wilfredo Morales

Glenn Research Center, Cleveland, Ohio

Robert F. Handschuh and Timothy L. Krantz

U.S. Army Research Laboratory, Glenn Research Center, Cleveland, Ohio

Prepared for the

62nd Annual Meeting and Exhibition

sponsored by the Society of Tribologists and Lubrication Engineers

Philadelphia, Pennsylvania, May 6-10, 2007

National Aeronautics and

Space Administration

Glenn Research Center

Cleveland, Ohio 44135 
This report is a formal draft or working paper, intended to solicit comments and ideas from a technical peer group.

Level of Review: This material has been technically reviewed by technical management.

Available from

NASA Center for Aerospace Information 7115 Standard Drive

Hanover, MD 21076-1320
National Technical Information Service 5285 Port Royal Road Springfield, VA 22161

Available electronically at http://gltrs.grc.nasa.gov 


\title{
Feasibility Study of Vapor-Mist Phase Reaction Lubrication Using a Thioether Liquid
}

\author{
Wilfredo Morales \\ National Aeronautics and Space Administration \\ Glenn Research Center \\ Cleveland, Ohio 44135 \\ Robert F. Handschuh and Timothy L. Krantz \\ U.S. Army Research Laboratory \\ Glenn Research Center \\ Cleveland, Ohio 44135
}

\begin{abstract}
A primary technology barrier preventing the operation of gas turbine engines and aircraft gearboxes at higher temperatures is the inability of currently used liquid lubricants to survive at the desired operating conditions over an extended time period. Current state-of-the-art organic liquid lubricants rapidly degrade at temperatures above $300{ }^{\circ} \mathrm{C}$; hence, another form of lubrication is necessary. Vapor or mist phase reaction lubrication is a unique, alternative technology for high temperature lubrication. The majority of past studies have employed a liquid phosphate ester that was vaporized or misted, and delivered to bearings or gears where the phosphate ester reacted with the metal surfaces generating a solid lubricious film. This method resulted in acceptable operating temperatures suggesting some good lubrication properties, but the continuous reaction between the phosphate ester and the iron surfaces led to wear rates unacceptable for gas turbine engine or aircraft gearbox applications. In this study, an alternative nonphosphate liquid was used to mist phase lubricate a spur gearbox rig operating at 10,000 rpm under highly loaded conditions. After 21 million shaft revolutions of operation the gears exhibited only minor wear.
\end{abstract}

\section{Introduction}

Advances in the development of future jet and rotorcraft engines will depend on the successful high temperature lubrication of the engine bearings and gears. Current state of the art liquid lubricants provide excellent protection over a moderate temperature range, but unfortunately at temperatures above $300{ }^{\circ} \mathrm{C}$ these advanced liquid lubricants will degrade rapidly via thermal and oxidation decomposition. Due to the thermal limitations exhibited by conventional liquid lubricants, vapor or mist phase reaction lubrication (VMPL) has received a great deal of attention as an alternative method for high temperature lubrication.

Before proceeding, clarification of the term VMPL will be addressed as some confusion exists regarding how it relates to other vapor or mist lubrication techniques. In a regular oil-mist lubrication system, mineral or synthetic hydrocarbon oil is delivered, in an air stream, as a fine oil mist to mechanical components where the oil- mist coagulates on the wearing surfaces providing lubrication. No intended reaction between the oil and the metal surfaces occurs and the oil functions as a normal liquid lubricant within its operating temperature range. In gaseous lubrication a light hydrocarbon gas, such as acetylene, is delivered to mechanical components operating at sufficiently high temperatures that the gas decomposes on the wearing surfaces generating a lubricious graphitic material which provides lubrication. In the VMPL method, an organic liquid is either vaporized or misted and delivered in an air stream to mechanical components operating at high enough temperatures that the organic molecules react in the wearing surfaces generating a lubricious deposit which provides effective lubrication. 
A number of VPML studies have utilized a liquid phosphate ester that was transported as a vapor or mist to bearings or gears where the phosphate ester reacted on the metal surfaces generating a lubricious iron-phosphate type film or deposit (refs. 1 and 2). VMPL studies on a variety of metallic and ceramic substrates have shown the need for a transition metal, such as iron, to be present in order for a film to be produced successfully (refs. 3 and 4). The chemical reaction between the phosphate ester and iron containing surfaces produces an iron-phosphorus type film also containing oxygen and carbon (refs. 5 to 7). This film has been shown to lubricate iron based surfaces at temperatures greater than $300{ }^{\circ} \mathrm{C}$ but at a price. Prolonged, continuous lubrication of bearings and gears led to excessive wear due to a constant rapid reaction between the phosphate ester and the iron. This rapid reaction between a phosphate ester vapor and a pure iron foil was studied using a modified thermal gravimetric analysis (TGA) unit (ref. 7). It was found that the reaction generated a phosphate type film on the iron surface which grew with time via a diffusion-reaction mechanism.

If the VPML method is to be successfully used in future applications then the excessive wear problem must be minimized. One possible solution is the use of an alternative, non-phosphorus reactive organic liquid. In references 8 and 9, Morales investigated some of the properties of a polyphenyl thioether liquid. Polyphenyl thioethers are derivatives of polyphenyl ethers where one or more of the oxygen atoms in the polyphenyl ethers are replaced by sulfur atoms. Although the thioethers are thermally stable to $390{ }^{\circ} \mathrm{C}$, simple pin-on-disk tests conducted at $25^{\circ} \mathrm{C}$ revealed that they easily break down under boundary lubrication conditions leading to the formation of a polymeric type material. Morales subsequently demonstrated the polymer forming abilities of the thioethers under dynamic boundary lubricating conditions and under static conditions using an electrochemical cell. This polymeric material may well be lubricious and thus the use of the thioether as an alternate VMPL liquid was considered.

An initial investigation into the use of a thioether as a VMPL lubricant was conducted using a high temperature reciprocating pin-on-plate tribometer (ref. 10). The tests revealed that the thioether was able to lubricate a ceramic pin and plate pair, at temperatures greater than $450{ }^{\circ} \mathrm{C}$, with a coefficient of friction less than 0.05 with minimal wear of the substrates. Based on these outstanding results, a thioether liquid was tested as a VMPL lubricant using an enclosed spur gearbox rig operating under high loads and speeds. This paper reports the results of this test with particular attention to the wear of the spur gears.

\section{Test Specimens, Test Rig, and Procedure}

The thioether lubricant used in this study is actually a blend of four chemical components (fig. 1) consisting of one 3-ring phenyl component and three 4-ring phenyl components. These four components were blended by a commercial company in order to produce a thioether liquid lubricant with a pour point of $-29{ }^{\circ} \mathrm{C}$ (ref. 9) for potential aerospace applications.

The test gears used for this study were case-carburized and ground AISI 9310 spur gears. The spur gear geometry is provided in table 1 . The gears provided a lead crown having a radius of $323 \mathrm{~mm}$ (12.7 in.). This crown provides an approximate $0.014 \mathrm{~mm}(0.00055 \mathrm{in}$.) rise across the nominal facewidth of $6.35 \mathrm{~mm}$ ( $0.250 \mathrm{in}$.). The gear geometry accuracies were inspected using a coordinate measuring machine. The gear profile and tooth spacing geometry quality was found to be ANSI-AGMA 2000-A88 class 11 which is aerospace quality. The lead crown geometry was also verified using the coordinate measuring machine inspection data. The nominal chemical composition and heat treatment procedure for the test gears are provided in tables 2 and 3 . The specified surface hardness of the test gears, as provided by the commercial supplier, was Rockwell C 58-62. 
(a)<smiles>c1ccc(Oc2cccc(Sc3cccc(Oc4ccccc4)c3)c2)cc1</smiles>

(b)<smiles>c1ccc(Oc2cccc(Sc3cccc(Sc4ccccc4)c3)c2)cc1</smiles>

(c)<smiles>Cc1ccccc1</smiles><smiles>Cc1cccc(C)c1</smiles><smiles>Cc1cccc(I)c1</smiles><smiles>Sc1ccccc1</smiles>

(d)<smiles>[131I]c1ccc(Sc2cccc(Sc3ccccc3)c2)cc1</smiles>

Figure 1.-Chemical components of thio-ether. (a) 1, 1-thiobis [3-phenoxybenzene]; molecular weight, 370. (b) 1-phenoxy-3-[[3-(phenylthio) phenyl] thio] benzene; molecular weight, 386. (c) 1, 1-thiobis [3-(phenylthio) benzene]; molecular weight, 402. (d) 1, 3-bis (phenylthio) benzene; molecular weight, 294.

TABLE 1.-SPUR TEST GEAR DESIGN PARAMETERS [GEAR TOLERANCES ARE PER ANSI-AGMA CLASS 11.]

\begin{tabular}{|l|r|}
\hline Number of teeth & 28 \\
\hline Module, mm (in.) & $3.18(0.125)$ \\
\hline Diametral pitch, in. $^{-1}$ & 8 \\
\hline Circular pitch, mm (in.) & $9.975(0.3927)$ \\
\hline Whole depth, mm (in.) & $7.62(0.300)$ \\
\hline Addendum, mm (in.) & $3.18(0.125)$ \\
\hline Chordal tooth thickness ref., mm (in.) & $4.85(0.191)$ \\
\hline Pressure angle, deg. & 20 \\
\hline Pitch diameter, mm (in.) & 88.90 (3.500) \\
\hline Outside diameter, mm (in.) & $95.25(3.750)$ \\
\hline Root fillet, mm (in.) & 1.02 to 1.52 (0.04 to 0.06) \\
\hline Measurement over pins, mm (in.) & 96.03 to 96.30 (3.781 to 3.791) \\
\hline Pin diameter, mm (in.) & $5.49(0.216)$ \\
\hline Backlash reference, mm (in.) & $0.254(0.010)$ \\
\hline Lead crown radius, mm (in.) & $323(12.7)$ \\
\hline
\end{tabular}

TABLE 2.-NOMINAL CHEMICAL COMPOSITION OF AISI 9310 GEAR MATERIAL

\begin{tabular}{|l|l|}
\hline \multicolumn{1}{|c|}{ Element } & $\begin{array}{l}\text { Weight, } \\
\text { percent }\end{array}$ \\
\hline Carbon & 0.10 \\
\hline Nickel & 3.22 \\
\hline Chromium & 1.21 \\
\hline Molybdenum & 0.12 \\
\hline Copper & 0.13 \\
\hline Manganese & 0.63 \\
\hline Silicon & 0.27 \\
\hline Sulfur & 0.005 \\
\hline Phosphorous & 0.005 \\
\hline Iron & Balance \\
\hline
\end{tabular}


TABLE 3.-HEAT TREATMENT FOR AISI 9310 GEARS

\begin{tabular}{|c|l|c|c|c|}
\hline \multirow{2}{*}{ Step } & \multicolumn{1}{|c|}{ Process } & \multicolumn{2}{|c|}{ Temperature } & \multirow{2}{*}{$\begin{array}{c}\text { Time, } \\
\text { hr }\end{array}$} \\
\cline { 3 - 4 } & & $\mathrm{K}$ & ${ }^{\circ} \mathrm{F}$ & \\
\hline 1 & Preheat in air & ----- & ----- & ----- \\
\hline 2 & Carburize & 1,172 & 1,650 & 8 \\
\hline 3 & $\begin{array}{l}\text { Air cool to room } \\
\text { temperature }\end{array}$ & ----- & ----- & ----- \\
\hline 4 & Copper plate all over & ----- & ----- & ----- \\
\hline 5 & Reheat & 922 & 1,200 & 2.5 \\
\hline 6 & $\begin{array}{l}\text { Air cool to room } \\
\text { temperature }\end{array}$ & ----- & ----- & ----- \\
\hline 7 & Austentize & 1,116 & 1,550 & 2.5 \\
\hline 8 & Oil quench & ----- & ----- & ----- \\
\hline 9 & Subzero cool & 189 & -120 & 3.5 \\
\hline 10 & Double temper & 450 & 350 & 2 each \\
\hline 11 & Finish grind & ----- & ----- & ----- \\
\hline 12 & Stress relieve & 450 & 350 & 2 \\
\hline
\end{tabular}

The spur gearbox test facility used in this study is shown in figure 2. A detailed description and explanation on the operation of this facility is given in reference 1. In this study the spur gearbox was modified to accommodate a misting unit (fig. 3). The mister was filled with the thioether and both were kept at room temperature. Dried and filtered compressed shop air was then used to deliver the thioether to the spur gearbox as an extremely fine mist. This delivery method was chosen because previous studies showed that the VMPL lubricant could be delivered successfully as either a vapor or a mist (refs. 1 and 2). The mister was adjusted to deliver about $15 \mathrm{ml} / \mathrm{hr}$ of thioether in a flowing air stream of about $400 \mathrm{l} / \mathrm{hr}$. The outlet of the gearbox was connected to a condensing unit where most of the thioether was collected. The flowing air was vented from the condensing unit. A thermocouple was installed inside the

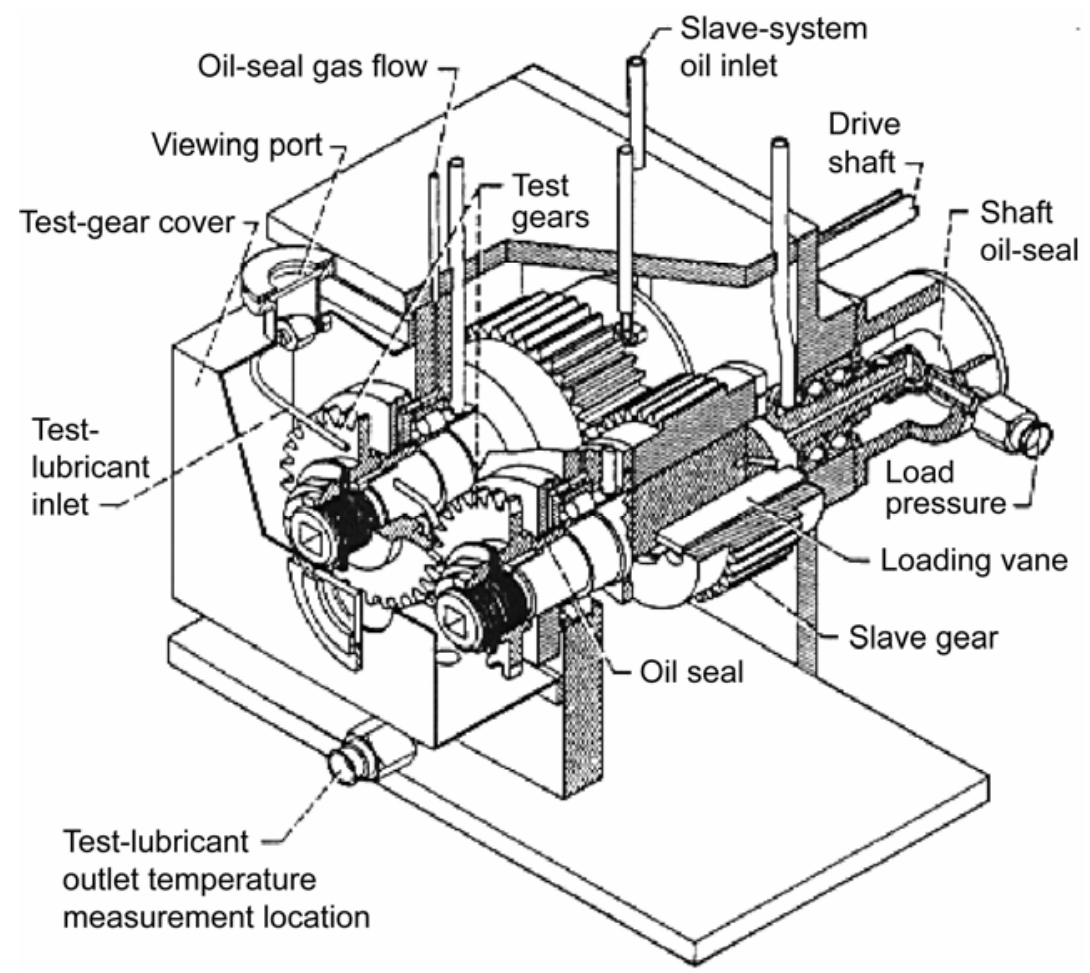

Figure 2.-Spur gear fatigue rig used for conducting tests. 

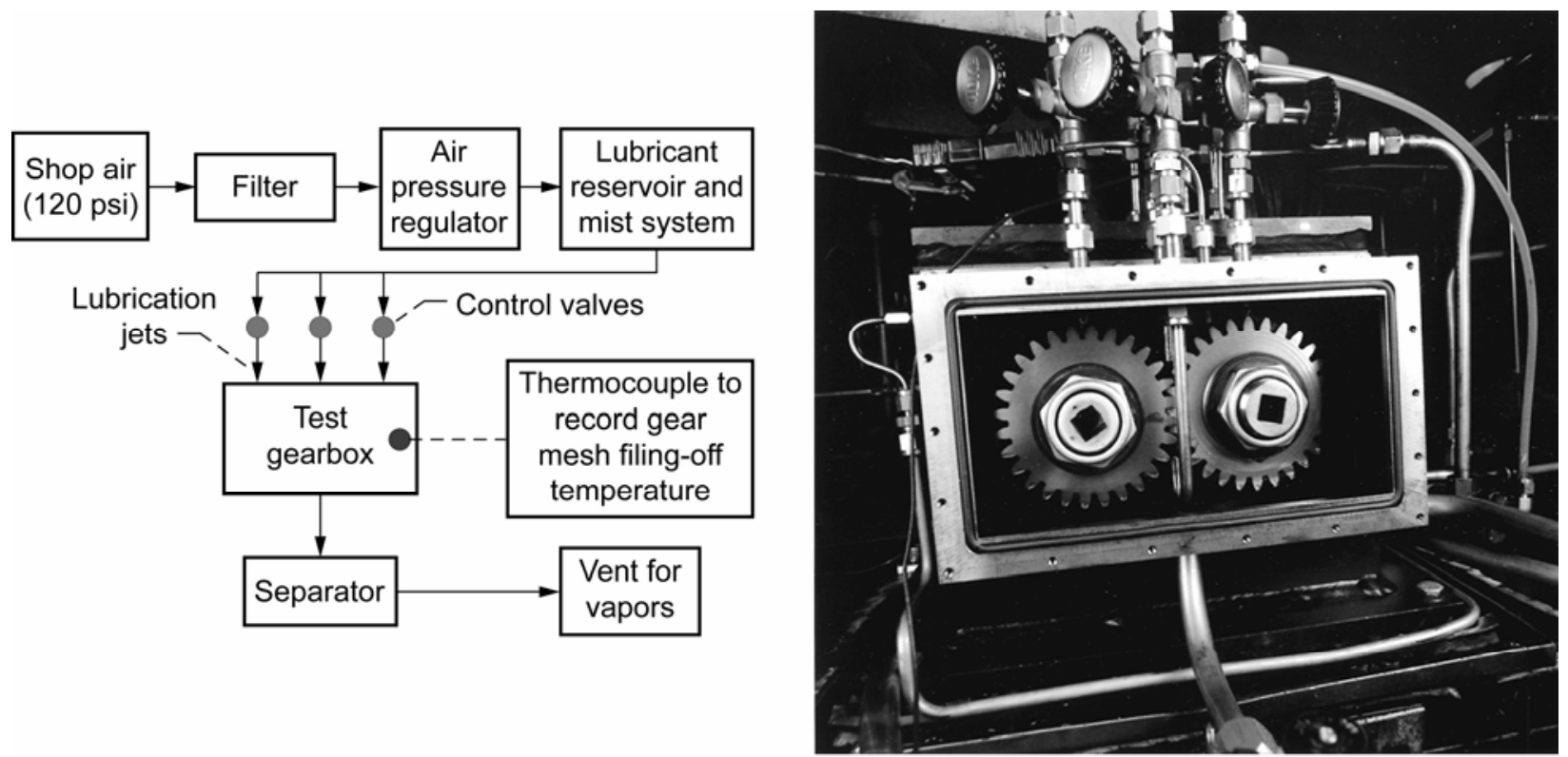

Figure 3.-(a) Vapor/mist phase lubrication system. (b) Photograph of experimental test arrngement.

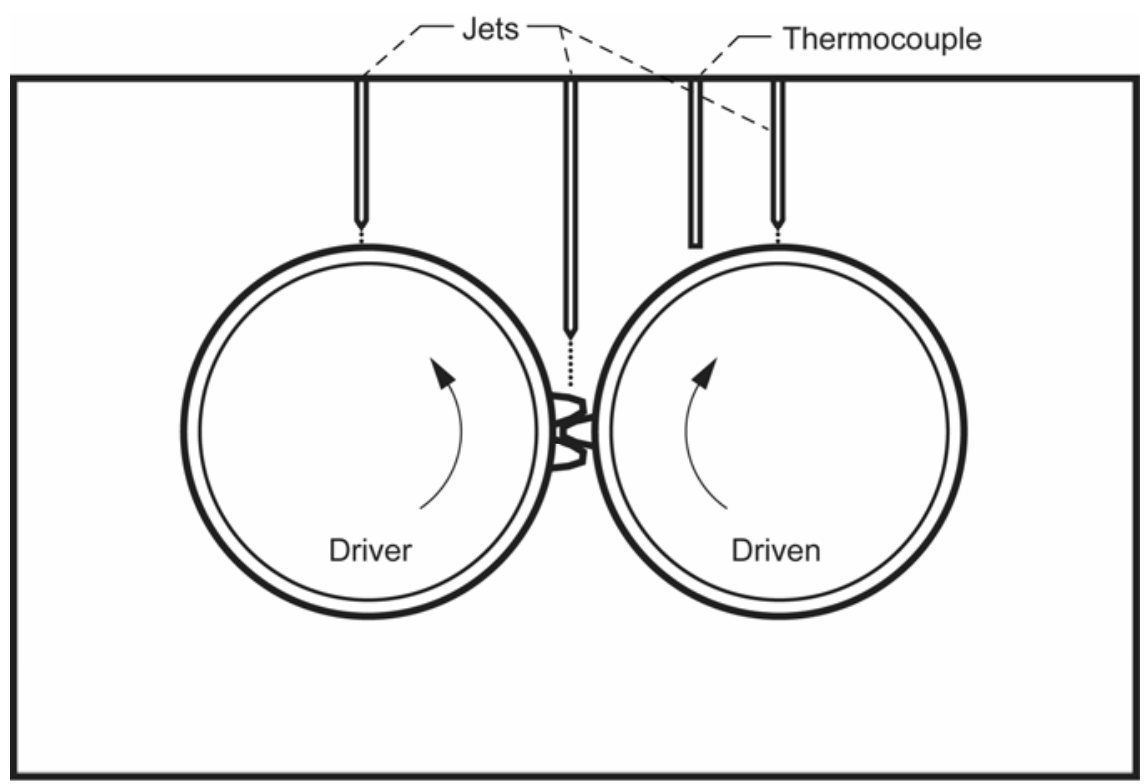

Figure 4.-Spur gearbox showing jet and thermocouple placement. Each gear has twenty eight teeth, only a select few shown here.

gearbox to record the temperature of the turbulent air near the rotating gears. The thermocouple was located close to the position where the meshing gear teeth disengage, the so-called "fling-off" position (fig. 4). Accelerometers monitored the gearbox housing vibration.

Two AISI 9310 spur gears, cleaned and weighed, were installed with faces aligned. Note that figure 2 depicts test gears installed with faces offset as has been used for gear surface fatigue tests using test gears with zero lead crowning. For the present work, gears with lead crowning were employed and so gears were operated with faces aligned having zero face offset. After the gears were installed, a transparent plexiglass cover was bolted to the front of the gearbox (fig. 3(b)) sealing it. The plexiglass cover allowed one to view the gears in operation and measure their speed using a tachometer. The test started by first slowly rotating the gears under a light load and then turning on the mister. As soon as the thioether mist 
was observed inside the gearbox, both speed and load were increased to test conditions of 10,000 rpm speed and gear tooth force of $516 \mathrm{~N}$ (116 lb force). The speed and load were adjusted gradually over a 2 min period allowing for a short break-in period. The tooth force stated is the force normal to the tooth surface (tangent to the base circle) for static equilibrium. Hertzian analysis was done for operation at the pitch-point and by assuming static equilibrium. At test conditions the nominal contact ellipse size was 2.42 by $0.337 \mathrm{~mm}$ (0.0954 by $0.0133 \mathrm{in}$.) and peak contact pressure was $1.2 \mathrm{GPa}(175,000 \mathrm{psi})$.

The testing was completed over six test sessions (table 4). In total the gears were operated at the test load and speed for 21 million cycles. At the end of the test, the spur gears were removed, cleaned and weighed. Surface profile measurements of several gear teeth were taken before and after testing.

TABLE 4.-TESTING TIME SUMMARY

\begin{tabular}{|c|c|c|}
\hline Test session & $\begin{array}{c}\text { Operating time, } \\
\text { min }\end{array}$ & $\begin{array}{c}\text { Shaft rotations } \\
\text { accumulative, } \\
\text { millions of cycles }\end{array}$ \\
\hline 1 & 330 & 3.3 \\
\hline 2 & 429 & 7.6 \\
\hline 3 & 419 & 11.8 \\
\hline 4 & 393 & 15.7 \\
\hline 5 & 234 & 18.0 \\
\hline 6 & 316 & 21.2 \\
\hline
\end{tabular}

\section{Results and Discussion}

The thermocouple temperature and vibration readouts for the first and final test sessions are shown in figures 5 and 6. At the start of the first test session, as the gear speed was increased to 10,000 rpm and the load applied, the thermocouple temperature increased to near $121{ }^{\circ} \mathrm{C}$, then decreased to about $107{ }^{\circ} \mathrm{C}$ and held steady at this temperature for $320 \mathrm{~min}$. During this time the vibration readout quickly increased to $15 \mathrm{~g}$ (rms) and remained steady at this reading until the spur gearbox rig was shut down. At the end of test session one, visual inspection of the gears revealed no gross wear. When testing resumed the next day, the
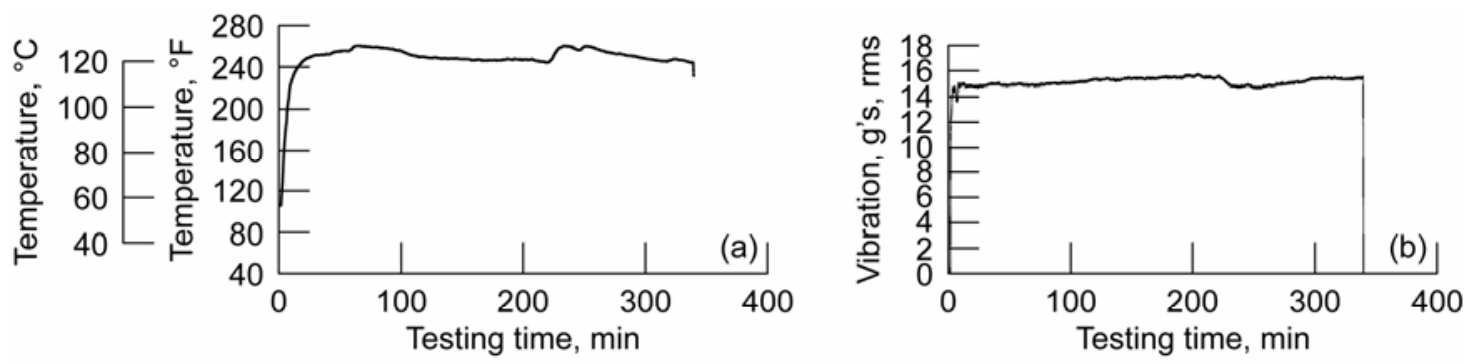

Figure 5.-(a) Trends of the (a) oil mist temperature and (b) housing vibration during testing session number 1.
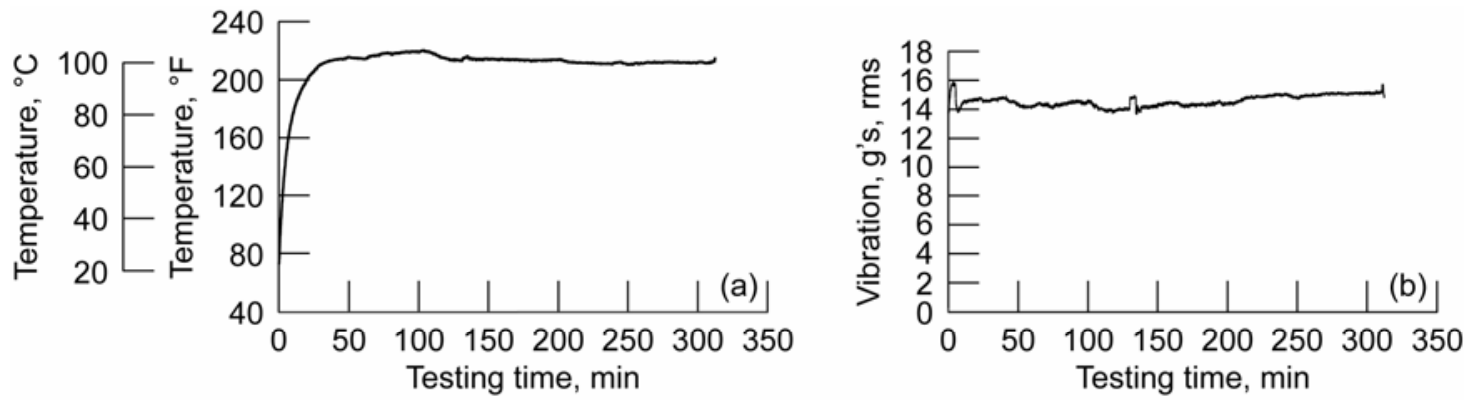

Figure 6.-(a) Trends of the (a) oil-mist temperature and (b) housing vibration during final testing session number 6 . 


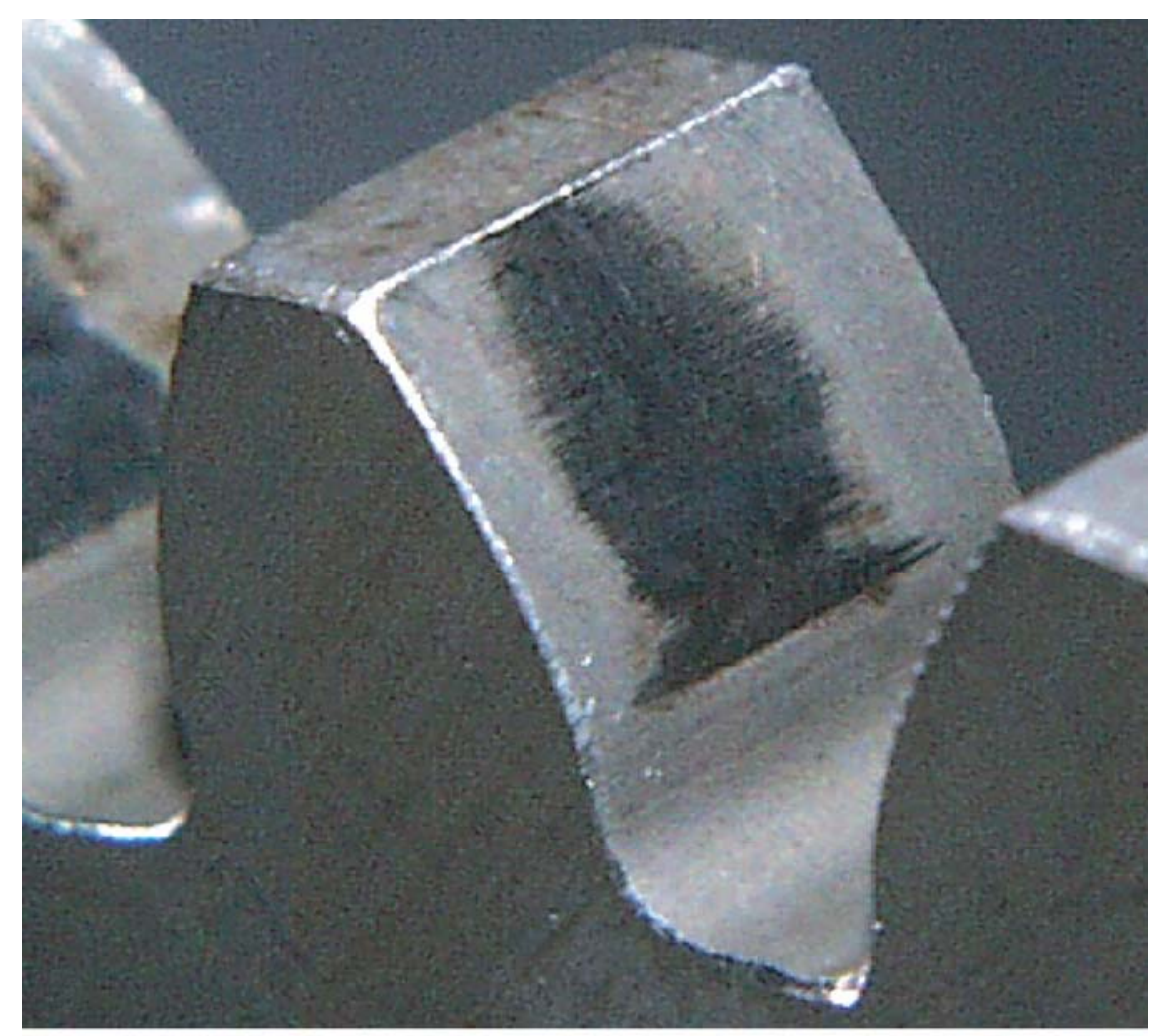

Figure 7.-Typical condition of gear tooth surface after 7.6 million shaft revolutions at test speed and load.
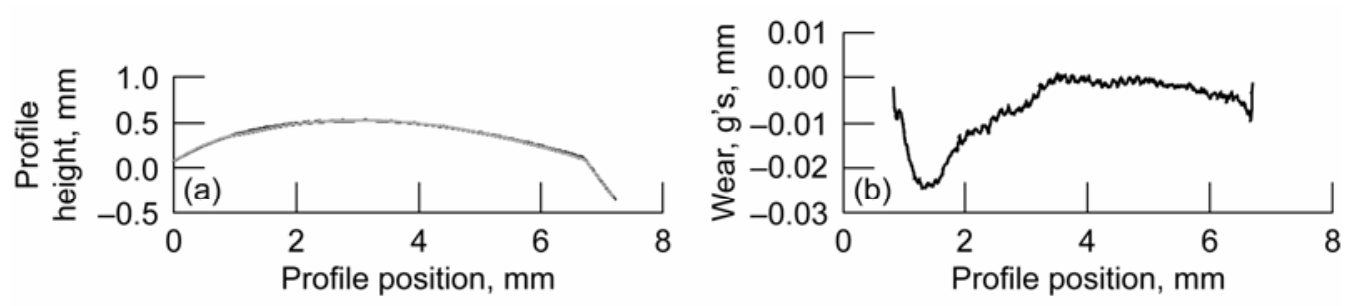

Figure 8.-(a) Typical suface profile measurements of a spur gear tooth before and after a test.

(b) Wear difference profile of the spur gear tooth.

thermocouple temperature again increased to and remained steady near $107^{\circ} \mathrm{C}$ while the vibration reading leveled out at $15 \mathrm{~g}$ (rms). This behavior repeated itself over the next four test sessions. At the end of test session 2 visible inspection of the gears revealed that the contacting portions of the tooth surfaces showed a running-in type polishing wear of asperities (fig. 7). The final 4 test sessions showed similar trends and results. The total accumulative testing time was $2120 \mathrm{~min}$ or $35.3 \mathrm{hr}$ (21.2 million shaft revolutions). It should be mentioned that no traces of coking on the gears was noticed as occurred when gears were vapor-mist lubricated using synthetic paraffinic oil (ref. 11).

Table 5 lists the masses of the two spur gears before and after the tests. Spur gear \#1 (the driving pinion) lost $8 \mathrm{mg}$ of material and spur gear \#2 (the driven gear) lost $6 \mathrm{mg}$. In terms of percentages this represents losses less than 0.002 percent. Figure 8(a) shows typical surface profile measurements of a spur gear tooth before and after a test. As can be seen the surface profiles overlap to a near identical match. Figure 8(b) shows the wear difference profiles of the spur gear tooth. This figure is generated by subtracting the "after test" profile from the "before test" profile. Very little wear is observed. 
TABLE 5.-GEAR MASSES

\begin{tabular}{|c|c|c|}
\hline \multicolumn{3}{|c|}{ TABLE 5.—GEAR MASSES } \\
\hline & $\begin{array}{c}\text { Before test, } \\
\mathrm{g}\end{array}$ & $\begin{array}{c}\text { After test, } \\
\mathrm{g}\end{array}$ \\
\hline Gear \#1 & 402.3146 & 402.3065 \\
\hline Gear \#2 & 402.1564 & 402.1503 \\
\hline
\end{tabular}

The results from this study clearly showed a dramatic improvement over the results from previous studies (ref. 11), using a synthetic paraffinic oil and a phosphate ester oil, in several respects. For instance, the primary evidence that good lubrication was provided, using the thioether, was the observed minimal gross wear on the gear teeth even after $35 \mathrm{hr}$ of operation. Gear tooth wear, however, was observed using the paraffinic oil and phosphate ester after only 10 min of operation. The fling-off thermocouple temperature readings for the thioether test was constant at $107^{\circ} \mathrm{C}$ with no fluctuation, whereas for the previous tests the temperatures were much higher, in some cases approaching $205^{\circ} \mathrm{C}$, and the temperatures fluctuated up and down. No coking was observed on the gears in this study using the thioether lubricant whereas substantial coking was present in the VPLM tests using the paraffinic oil.

\section{Conclusions}

A thioether was used as a VMPL lubricant to successfully lubricate a spur gearbox rig operating at 10,000 rpm and a torque load level corresponding to a 1.2 GPa maximum Hertz pressure at the pitch-line for over 21 million shaft revolutions. The use of the thioether resulted in minimal wear of the spur gears in contrast to previous studies using phosphate esters. This study has demonstrated that the thioether is clearly superior to the traditional phosphate esters as a VMPL lubricant and has clear potential for practical applications.

\section{References}

1. Morales, W. and Handschuh, R.F., "A Preliminary Study on the Vapor/Mist Phase Lubrication of a Spur Gearbox,” Lubr. Eng., 56 (9), pp. 14-19, (2000).

2. Van Treuren, K.W., Barlow, D.N., Helser, W.H., Wagner, M.J. and Forster, N.H., "Investigation of Vapor-Phase Lubrication in a Gas Turbine Engine,” Journal of Engineering for Gas Turbines and Power, vol. 120, pp. 257-262, (1998).

3. Reye, J.T., McFadden, L.S., Gatica, J.E. and Morales, W., "Conversion Coatings for Aluminum Alloys by Chemical Vapor Deposition Mechanisms,” NASA/TM-2004-21290 (2004).

4. McFadden, L.S., Garrido, C., Reye, J.T., Morales, W. and Gatica, J.E., "Study of Catalytic Reactions as Mechanisms of High Temperature Lubrication,” Lubr. Eng., 58 (12), pp. 34-36, (2002).

5. Klaus, E.E., Phillips, J., Lin, S.C., Wu, N.L. and Duda J.L., "Structure of Films Formed During the Deposition of Lubrication Molecules on Iron and Silicon Carbide,” Tribology Transactions, 33 (1) pp. 25-32, (1988).

6. Johnson, D.W., Morrow, S., Forster, N.H. and Saba, C.S., "Vapor Phase Lubrication: Reaction of Phosphate Ester Vapors with Iron and Steel,” Chem. Mater. vol. 14. no. 9, pp. 3767-3775, (2002).

7. Nagarajan, A., Garrido, C., Gatica, J.E. and Morales, W. "Phosphate Reactions as Mechanisms of High-Temperature Lubrication,” NASA/TM-2006-214060, (2006).

8. Morales, W. "High Pressure Liquid Chromatography: A Brief Introduction and Its Application to Analyzing the Degradation of a Thioether Liquid Lubricant,” NASA TM-83474, (1983).

9. Morales, W. "Simulation of Lubricating Behavior of a Thioether Liquid Lubricant by an Electrochemical Method,” ASLE Transactions, vol. 29, 1, pp. 67-74, (1985).

10. Morales, W., Graham, E. and Galvin, T. "Vapor Phase Lubrication using a Thioether," Lubrication Engineering, vol. 54, no. 3, (1997).

11. Handschuh, R.F. and Morales, W. "Lubrication System Failure Baseline Testing on an Aerospace Quality Gear Mesh,” NASA/TM—2000-209954, May (2000). 


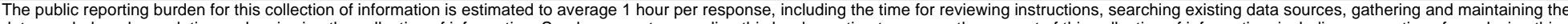

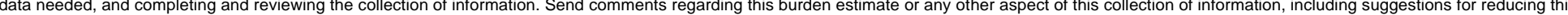

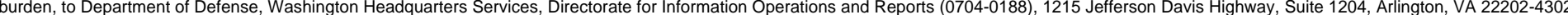

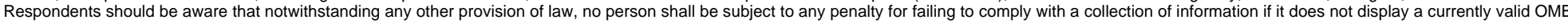
control number.

PLEASE DO NOT RETURN YOUR FORM TO THE ABOVE ADDRESS

\section{REPORT DATE (DD-MM- $Y Y Y Y)$ \\ 2. REPORT TYPE \\ 3. DATES COVERED (From - To)}

01-12-2007

\section{TITLE AND SUBTITLE}

Technical Memorandum

Feasibility Study of Vapor-Mist Phase Reaction Lubrication Using a Thioether Liquid

5b. GRANT NUMBER

5c. PROGRAM ELEMENT NUMBER

\section{AUTHOR(S)}

Morales, Wilfredo; Handschuh, Robert, F.; Krantz, Timothy, L.

\section{5d. PROJECT NUMBER}

5e. TASK NUMBER

5f. WORK UNIT NUMBER

WBS 877868.02.07.03.01.01

\section{PERFORMING ORGANIZATION NAME(S) AND ADDRESS(ES)}

National Aeronautics and Space Administration

8. PERFORMING ORGANIZATION

REPORT NUMBER

John H. Glenn Research Center at Lewis Field

E-16223

Cleveland, Ohio 44135-3191

\section{SPONSORING/MONITORING AGENCY NAME(S) AND ADDRESS(ES)}

National Aeronautics and Space Administration

Washington, DC 20546-0001

\section{TPONSORINGIMONITORS ACRONYM(S) \\ NASA}

11. SPONSORING/MONITORING REPORT NUMBER

NASA/TM-2007-215035

\section{DISTRIBUTIONIAVAILABILITY STATEMENT}

Unclassified-Unlimited

Subject Categories: 01 and 23

Available electronically at http://gltrs.grc.nasa.gov

This publication is available from the NASA Center for AeroSpace Information, 301-621-0390

\section{SUPPLEMENTARY NOTES}

\section{ABSTRACT}

A primary technology barrier preventing the operation of gas turbine engines and aircraft gearboxes at higher temperatures is the inability of currently used liquid lubricants to survive at the desired operating conditions over an extended time period. Current state-of-the-art organic liquid lubricants rapidly degrade at temperatures above $300{ }^{\circ} \mathrm{C}$; hence, another form of lubrication is necessary. Vapor or mist phase reaction lubrication is a unique, alternative technology for high temperature lubrication. The majority of past studies have employed a liquid phosphate ester that was vaporized or misted, and delivered to bearings or gears where the phosphate ester reacted with the metal surfaces generating a solid lubricious film. This method resulted in acceptable operating temperatures suggesting some good lubrication properties, but the continuous reaction between the phosphate ester and the iron surfaces led to wear rates unacceptable for gas turbine engine or aircraft gearbox applications. In this study, an alternative non-phosphate liquid was used to mist phase lubricate a spur gearbox rig operating at 10,000 rpm under highly loaded conditions. After 21 million shaft revolutions of operation the gears exhibited only minor wear.

\section{SUBJECT TERMS}

Chemistry; Vapor phase lubrication; Gears; Tribology

\section{SECURITY CLASSIFICATION OF:}

a. REPORT

$\mathrm{U}$

\section{b. ABSTRACT} $\mathrm{U}$

\section{LIMITATION OF} ABSTRACT

UU
18. NUMBER PAGES

14 19a. NAME OF RESPONSIBLE PERSON

STI Help Desk (email:help@sti.nasa.gov)

19b. TELEPHONE NUMBER (include area code) 301-621-0390 

